Bhat, Chandrashekhar (2018): Indian Diaspora and Global Organizations: Communities and Contested Boundaries. In: Elfriede Hermann and Antonie Fuhse (eds.): India Beyond India: Dilemmas of Belonging. Göttingen: Göttingen University Press (Göttingen Series in Social and Cultural Anthropology, 12), pp. 27-48. Doi: 10.17875/gup2020-1262

\title{
2 Indian Diaspora and Global Organizations: Communities and Contested Boundaries
}

\author{
Chandrashekhar Bhat
}

\section{Introduction}

This chapter focuses on the emergence of Indian diaspora organizations operating at the global level to articulate their socio-cultural, economic and political interests. The Indian diaspora comprises communities no less diversified than those found in the land of origin, often reflecting these diversities through a wide variety of ethnic minority associations. Unlike the ethnic associations of Indian immigrants, which are formed specifically to address their immediate concerns in the context of adjustment and integration into the 'host society,' the diaspora organizations are essentially transnational, uniting global collectives based on national, subnational, linguistic, caste or religious identities. These diversities are further compounded on a temporal plane, differentiating the descendants of early colonial indentured immigrants (PIO, i.e. the Persons of Indian Origin diaspora) from later immigrants who left after India's Independence (NRI, i.e. the Non-Resident Indian diaspora). The dynamics of these diversities carry implications for the grouping and regrouping of Indian diaspora communities: all of them compete and contend in their efforts to form global organizations.

This chapter explores the formation of pan-Indian Global Organizations of People of Indian Origin (GOPIO) and the regional/linguistic organizations formed, for example, by the Telugu, Gujarati and Punjabi communities. The state response, which is to engage these diaspora organizations at both the national and sub-national levels via new policy initiatives, is another significant development in the new millennium toward bridging India beyond India. 
Recent population estimates suggest that the Indian diaspora has grown far beyond 25 million, scattered as it is around the globe in more than 110 countries. The numbers run to over 10,000 in 48 countries and have reached the half million mark in 11 countries (Ministry of External Affairs 2002). People of Indian origin represent a significant proportion of the population in countries such as Mauritius (60.69\%), Trinidad and Tobago (38.63\%), Guyana (51.93\%), Surinam $(36.04 \%)$, Fiji (41.34\%), South Africa (2.3\%) and Malaysia (7.2\%) and Singapore $(9.71 \%)$. Presently they constitute nearly ten million, according to the Ministry of External Affairs, ${ }^{1}$ and are spread across all continents. The descendants of the indentured labor immigrants from the erstwhile Central Provinces - Bhojpuri-speaking people from the present day states of Bihar and Eastern Uttar Pradesh - form the largest cluster of the PIO Diaspora, followed by those originating from the Tamil, Telugu and Malayalam speaking regions of South India. Indian immigrants constitute a 'visible' or 'model' minority in countries like Canada $(2.8 \%)$, the United Kingdom (2.11\%), New Zealand (1.45\%), Australia (1.02\%), and the USA (0.6\%). Almost all countries in West Asia or the Gulf Region have a substantial workforce (above $3,000,000)$ recruited from India, even though workers return to their places of origin after termination of their contracts. The Indian diaspora today comprises - broadly speaking - four streams following the diverse situations under which they emigrated. The nature and process of emigration and the destinations in question are briefly explained in terms of these distinct streams of emigration and settlement.

\section{The First Stream}

The first stream includes $3^{\text {rd }}$ to $5^{\text {th }}$ generation descendants of the early emigrants who migrated during the mid-nineteenth century. The main destinations were the British and European colonies in Africa, Southeast Asia, Fiji, and the Caribbean, where the newcomers were used as plantation labor and railway workers under what the British colonizers called 'indenture system,' which Tinker (1974) has rightly described as "a new system of slavery." According to Clarke, Peach, and Vertovec (1990), under this system some 1.5 million persons migrated to the above destinations. Robin Cohen (1997) has classified them as a "labor diaspora." Many lost contact with their 'motherland,' including their mother tongue, despite otherwise retaining salient features of their culture, including regional identities and religions. They may be called the 'PIO diaspora,' which is indeed how they call themselves, and should be distinguished from the later emigrants after India's independence, the 'NRI diaspora.' The former often recall that their great-grand parents and ancestors were enticed, or forced, to immigrate to unknown destinations on ships as 'cargo' from Calcutta and other ports, while the latter left on flights from airports for destinations in developed countries (the jahaji and the havayee jahaji). ${ }^{2}$

\footnotetext{
${ }^{1}$ Figures compiled from Ministry of External Affairs (2002: xvii-xx).

${ }^{2}$ Indenture laborers were transported to plantation colonies on ships chartered by recruiting agencies
} 


\section{The Second Stream}

The second stream consists of professionally trained and skilled emigrants to the developed countries of the West during the second half of the $20^{\text {th }}$ century, who settled down initially as Non-Resident Indians (NRIs) and in due course became 'green card' holders and naturalized citizens in their host countries. The NRI diaspora continues to take an interest in their place of origin, paying frequent visits to India and maintaining a vibrant interaction.

\section{The Third Stream}

The migrant labor force, semi-skilled and unskilled, to the countries of West Asia and the Gulf, including a few professionals like engineers and doctors, followed in the wake of the oil boom and forms the third stream. Many members of this stream have left behind their families in India and contribute to family maintenance with remittances; what is left of their saving they invest. The volume of remittances made by the Indian immigrants from West Asia is great, exceeding payments received from all other countries. They form the majority among the Non-Resident Indians (NRIs) or expatriate Indians and remain so till they return to their places of origin on termination of their work contracts, since they are invariably denied any citizenship rights and permanent residency in all the West Asian countries.

\section{The Fourth Stream}

Over the past three decades there has been unprecedented movement of highly trained professionals in the fields of information and communication technologies (ICT) and management and nursing, in order to meet the increasing demand for these services in the developed countries. These skilled workers initially emigrate to take up short term assignments ranging from 6 to 10 years under schemes like US H1 B VISA, paving the way for the 'green card,' which entitles bearers to permanent residency and, ultimately, naturalization and citizenship. They form the fourth stream.

Each stream of emigrants differs from the others in terms of the socio-economic and educational background under which the workers emigrated from India, the overseas destinations in question, and their socio-economic location in the host society. During their long stay and interactions with the host society, they further acquired certain distinctive socio-cultural features that often differentiated them from communities who immigrated elsewhere, but also from their kith and kin or descendants back home in their places of origin. However, the identities of belonging to a location or region or nation - say Bhojpuri, Punjabi, Tamil, Telugu, or some other

and during the course of their long journeys laborers unknown to each other evolved endearing bonds of brotherhood calling themselves jahaji or jahaji bhai. 
Indian region - emerge as a significant factor in the grouping and regrouping of diverse diaspora communities.

\section{The Diversity of the Indian Diaspora}

That the Indian diaspora is perhaps the most diversified among the world's diasporic communities cannot be overstated. Indeed, one recent Oxford University publication (Jayaram 2011) is exclusively devoted to Diversities in the Indian Diaspora. Foremost among these diversities is the distinction between the PIO and the NRI diasporas, as mentioned earlier. Not only have the workers varied in the contexts of their emigration and destinations, but they also differ in terms of their socio-economic background and degree of interaction with the motherland. While the NRI Diaspora has retained vibrant relationships with their families and communities in India, the majority of the PIO Diaspora have lost all contact with the motherland. In the course of their long journeys made by ship to distant destinations, the unknown co-passengers became jahaji bhai (literally meaning 'ship brother', a brotherly affinity owing to the fact that they were all sailing away together). In such a situation the emigrants lost their caste and religious identities to a large extent.

The overseas Indian communities formed during the colonial era were not even allowed access to members of their own folk who were attached to different plantations under the 'indenture' system, let alone to then existing means of transportation and communication that might have permitted them to engage with the motherland.

The Indian emigrants after India's independence, however, not only enjoyed the advantage of being professionally trained, urban middle class and Anglophone, but also earned an adequate income that could facilitate frequent visits home, as a result of which they could maintain their socio-economic and cultural networks with their places of origin.

\section{Language and Region}

Language and region are the next significant parameter of identity articulation and differentiation among the Indian diaspora. Following the States Reorganisation Act of 1956, language came to assume greater significance in the reorganization of India into federal states. The Indian diaspora, too, is differentiated on the basis of linguistic and regional belonging - there are, for instance, Bhojpuri, Gujarati, Punjabi, Tamil, and Telugu diaspora communities connected and networking across several nation states. 


\section{Religion and Caste}

Religion is yet another aspect of the multiple diversities within India, and so too is it within the Indian diaspora. As a result, we may distinguish between a Hindu diaspora (Vertovec 2000), a Muslim diaspora (Brah 1996), a Sikh diaspora (Tatla 1999), and a Jain diaspora (Jain 2009).

One cannot underestimate the importance of caste in contemporary India, so much so that the Government of India decided to reintroduce caste for purposes of classifying India's population in the most recent census of 2011; it will be recalled that classifying the population in terms of caste was discontinued after India became independent. It is therefore not surprising to find diaspora communities articulating their caste identities, especially among the NRI Indian diaspora. While browsing online for 'Patidar Samaj' in the United Kingdom, I discovered several diasporic organizations of Kadwa and Leuva Patidars based on regional and sub-caste identities. Immigrants belonging to the dominant castes of the Reddys and Kammas of Andhra Pradesh, the Vokkaligas and Lingayats of Karnataka, the Jats of Punjab and Haryana, for instance, maintain distinctive diasporic formations and networks worldwide to promote their socio-cultural, economic, and political interests.

\section{Early Ethnic Formations}

Pursuit of diversities is not new to Indian immigrants, a sizable population of whom have formed ethnic collectives on the basis of regional, religious, linguistic, or caste affiliations. Overseas Indians, as they were popularly known for decades until the 1990s, have been distinctively known for the maintenance of traditional culture and identity that they meticulously promoted in the countries of their settlement for almost two centuries. Although the emigration of Indians has been taking place since the early Christian era, the bulk of the Indian migration leading to diaspora formation occurred mainly during the colonial period from 1830 s to 1920 s, and after India's independence.

The need for migrants to organize themselves to collectively respond to the diverse contexts of their settlement is not a new phenomenon; several such organizations have successfully articulated issues of great concern to them. Such organizations are primarily minority ethnic associations, essentially local, regional, or national in their outlook. An important feature that distinguishes an ethnic association from other kinds of voluntary groups is the criterion of restricted membership. Whereas membership of an ethnic association is based on certain primordial features such as language, religion, race and culture, the voluntary associations are open to anyone who wants to be a member. It is common to find, for instance, associations formed by Gujarti, Punjabi, Tamil, Telugu, Bengali and Bhojpuri communities in the countries where such clusters of Indian immigrants are found. These associations reflect the magnitude and diversity of the diaspora. The Commission for Racial Equality in 
the United Kingdom, for example, listed as many as 577 associations of immigrants from the world over in Greater London alone. In each Borough Council area, there are as many as 20 to 25 associations (Bhat 1993) that serve one or multiple purposes, covering almost all immigrant requirements.

What has transformed over the past two to three decades is the networking of these immigrants and associations with their kith and kin, either back in the place of origin or in the other countries to which they have immigrated, resulting in the establishment of diasporic relations. As observed by James Clifford (1994: 311), the "diasporic language appears to be replacing, or at least supplementing, minority discourse," a phenomenon that was noted by the mid-1990s in the wake of contemporary globalization and is being mediated by great advances in technologies of travel and communication.

\section{Contemporary Globalization and Global Organizations}

By the end of the $20^{\text {th }}$ century, the process of globalization had moved beyond its initial association with the liberalization of markets and the growth of multinational corporations (MNCs) and transnational corporations (TNCs) and had spread over several nation states to include "...worldwide diffusion of practices, expansion of relations across continents, organization of social life on a global scale and growth of shared global consciousness" (Lechner 2005: 330). There is now an ever greater interdependence between nation states across borders, not merely in trade and commerce but in almost all aspects of life, ranging from, say, food, clothing, sports, music and entertainment to ideology and spiritualism. With the revolutionary advancement in technologies of information, communication and travel during the 1980s and 1990s, there has been steep increase in the global transfers of people, capital, technology, cultural commodities, media and ideologies across several nations.

The process of globalization is so complex today that no single theory can hope to explain its multifaceted manifestations. Hence scholars have attempted to conceptualize globalization from different perspectives. For instance, Robertson (1992) looked at the process from a cultural stance, demonstrating how the world is being compressed as global consciousness is spreading. He argued that technological and organizational (as I would emphasize) developments lead to the compression of the world and the creation of a global field, in which individuals and societies become part of a larger system of societies and come to identify themselves in relation to global standards. Globalization, according to Robertson, has produced a more integrated yet also differentiated world society. For instance, there is the phenomenon of glocalization (Robertson 1995), incorporating some of the global or universal features in local cultures while also incorporating local specificity at the global level. Taking the local - culture, commodities, media, cuisine - to global destinations is of particular interest to diaspora communities. 
Robin Cohen prefers to use the term 'diasporization' as a concept akin to globalization, for the two are inseparably enmeshed. According to Cohen (1997), globalization has enhanced the practical, economic and effective roles of diasporas, showing them to be particularly adaptive forms of social organization. The rise of global civil society, global citizenship, global governance, border-crossing nongovernmental organizations emerge as institutional arrangements of this globalization project.

Contemporary globalization is propelled by "sociotechnological infrastructure" (Nonini 2005: 565) - social uses and application of new technologies of communication and transport - accelerating the scale of movements of people, commodities, ideas and capital more than ever before.

India today has spread far beyond being a mere nation state; it is not just a place, space or territory, but encompasses the entire globe and is there wherever Indians are found, dispersed in countries like the United Kingdom, The Netherlands, Trinidad, Guyana, Surinam, Fiji, Malaysia, Uganda, South Africa, the USA, Canada, and Australia. India now stretches to all corners of the globe, to wherever Indians have remained Indians; as a result, we can speak without hyperbole of a global Indian family. Globalization today has given rise to a huge transnational social field (Levitt and Glick Schiller 2004) where Indian families and organizations extend their family, caste, linguistic, regional, or national ties across the globe.

\section{Emergence of Indian Diaspora Global Organizations}

The Indian diaspora launched the first Global Organization of the People of Indian Origin in 1989 at its New York Convention. There have been, of course, several religious organizations networking for the promotion of religious activities, such as Vishwa Hindu Parishad, International Swaminarayan Satsang Organization (I.S.S.O.), the World Sikh Organization, and the International Sikh Youth Federation. Operating across the globe, they pursue limited objectives. In addition, there are a variety of associations (often referred to as ethnic minority organizations in those countries where Indian immigrants are in a minority), all of which articulate a specific interest. One cannot underestimate the role of such associations, especially the support they offer immigrants in safeguarding their culture, economic interests, and political rights. A number of global diasporic issues, as well as leading personalities, have emerged from these structures operating at the grassroots level.

Diaspora, as an idea and a reality, today occupies a key position in the transnational space that is increasingly rendered accessible by contemporary globalization. Diaspora communities dispersed around the world have established global organizations, transcending the boundaries of multiple nation states. In addition, they have initiated dialogue among themselves and with their countries of origin and residency in order to provide mutual support for socio-economic and political advancement. The term 'diaspora global organization' is used here to refer to voluntary associations formed by diaspora communities, or a single community, that enrolls members from 
across all nations. They reach out concerning the issues that possess relevance for those now dispersed from their original homeland or place of origin.

Global organizations initiated by the Indian diaspora may be broadly assigned to two categories:

- global organizations based on pan-Indian identity, and

- global organizations based on regional/linguistic, religious and caste identities.

\section{Pan-Indian Global Organizations}

In the First Global Convention of People of Indian Origin (New York, August 28 September 3, 1989), the largest representation ever of Indian immigrants from different parts of the world, it was decided to set up the Global Organization of People of Indian Origin. GOPIO is a voluntary, non-partisan, non-sectarian, global organization mandated to promote the interests of people of Indian origin worldwide. Over 3000 delegates attended it, representing almost all countries where an Indian diaspora is present. The Convention passed a number of resolutions to promote the interest of the entire diaspora community, addressing issues ranging from the violation of the political and civil rights of the Indian community, to seeking human rights and gender justice, and also changing the image of India. ${ }^{3}$ But soon (within a span of just three years) there emerged serious differences pertaining to leadership, causing a split to open up between the PIO and NRI.

The split came to the fore when a section of GOPIO, who subsequently established the PIO capital in Mauritius - henceforth referred to as GOPIO (M) organized the $2^{\text {nd }}$ GOPIO International Convention (Paris, 1992), whereas the other section, mostly comprising NRI, continued to run GOPIO from its New York headquarters and proceeded to hold their own $2^{\text {nd }}$ Global Convention (New Delhi, 1993). Both GOPIOs have successfully mobilized Indian diaspora the world over. While GOPIO (M) traces its origin to a first meeting held in the United Kingdom back in 1988, followed by the First Global Convention held in New York a year later, GOPIO (NY) claims that it was established after that First Global Convention organized by the National Federation of Indian American Associations (NFIA).

\section{Global Organization of People of Indian Origin (Mauritius)}

Following the Global Convention of New York, GOPIO (M) has so far organized eleven International conventions: from Paris they moved to Montreal, Canada for the $3^{\text {rd }}$ convention in 1994 , to Mauritius in 1996 for the $4^{\text {th }}$ convention (at which time Mauritius was declared PIO Capital with state support), to Durban for the

\footnotetext{
${ }^{3}$ GOPIO website (http://www.gopio.net/first_convention.htm) provides detailed information on the First Convention, Convention Resolutions, formation of Global Organization of People of Indian Origin (GOPIO), Constitution etc.
} 
$5^{\text {th }}$ convention in 1998 , to New Delhi in 2000 for the $6^{\text {th }}$ convention, and the $7^{\text {th }}$ convention was held again in Mauritius during 2003. The $8^{\text {th }}$ and the $9^{\text {th }}$ conventions were organized in Singapore and Kuala Lumpur respectively in 2005 and 2008. Durban was again the venue for the $10^{\text {th }}$ convention in 2010 to commemorate the $160^{\text {th }}$ year of Indian arrival in South Africa, and the $11^{\text {th }}$ convention was recently held in Kuala Lumpur. GOPIO (M) is supported by diaspora communities in Fiji, Malaysia, Singapore, Mauritius, Reunion, Guadeloupe, France, and South Africa. They consider themselves an inclusive Indian diaspora, as demonstrated by incorporating Francophone Indians. Mauritius is Francophone by choice, though the official language is English, so there is the advantage of bringing together diasporic communities that are either Francophone or Anglophone.

GOPIO (M) has 15 members in the Executive Committee, out of which 10 members are from the PIO diaspora, 2 from the NRI diaspora, and 3 from India. Among the prominent leaders responsible for the promotion of GOPIO (M) was the late Sri Dhundev Bahadoor, a social worker who established the Human Service Trust of Mauritius. Others included Sri Baleshwar Agrawal, the founder of Anther Rastriya Sahayog Parishad in Delhi, Mr. Selvarajoo Sundaram, a businessman from Malaysia, Mr. Mahendra Utchanna (President, GOPIO International), a former minister in Mauritius and businessman, Prof. Dasrath Chetty of Kwazulu-Natal University, South Africa, and Mr. Devraj, a former MP from Sri Lanka.

GOPIO (M) has been holding its conventions in Delhi at the ICCR auditorium or the ASSOCHEM Hall, which are not expensive venues. Recently they have been organizing their meetings at the Hotel Meridian, a French franchise, symbolizing their affinity and concern with the Francophone Indian communities residing in the former French colonies.

\section{Global Organization of People of Indian Origin (New York)}

GOPIO (NY), which draws its support from the National Federation of Indian American Associations (NFIA), the Associations of Indians in America (AIA), and the Indian American Forum for Political Education (IAFPE), organized its Second Global Convention in 1993 in New Delhi. It organized the Global Convention '99 to mark its $10^{\text {th }}$ Anniversary Celebrations (New York, September 24-26, 1999), as well as holding Global Conventions in various European cities (Zurich in 2000 and Leiden in 2002).

An analysis of the leadership pattern in GOPIO (NY) points to a controlling influence over the organization by the elite of the NRI diaspora, who are first generation immigrants to the United States. GOPIO (NY) appears to be synonymous with the person of Dr. Thomas Abraham, who holds a doctorate in chemistry from Columbia University, in the role of the President/Chairman of GOPIO International. Then there is Dr. Jagat Motwani, who holds a doctorate from Fordham University, NY, and is a practicing psychotherapist, his role being that of Secretary General/International Coordinator. Also playing a leadership role are Inder Singh, a businessman 
from California, and Sunny Kulathakal, a businessman from Saudi Arabia. Except for the two office bearers - Mr. Ashook Ramsaran, the current president of GOPIO (NY) International, is an engineer of Guyanese origin with his own company, and Deo Gosine, a New York businessman of Trinidad and Tobago origin - all the rest (on the current committee of 19) are first generation immigrants from India. The majority of members of the GOPIO (NY) Executive Committee come from affluent sections of first generation Indians living in North America or Europe.

Today GOPIO (NY) has 25 chapters spread among 19 countries; of the 148 life members, most of them (about 96) come from the USA. The others are from India, Australia, the United Kingdom, Germany, Middle Eastern countries, and the Caribbean. The organization successfully runs a monthly online e-news bulletin, providing information and covering events in North America and Europe. GOPIO (NY) is organized along chapter lines: the United States and India have 6 chapters each, established in different parts of their respective countries, while the remaining 13 chapters are located in Australia, Europe, Fiji, Trinidad, Guyana, Suriname, South Africa, Mauritius, and Zimbabwe. They have been holding most of their programs in India at expensive locations, such as the FICCI auditorium and Hotel Claridges in Delhi.

Both the GOPIOs were about a decade old when the Government of India, under Prime Minister Atal Bihari Vajpayee, decided in 2000 to set up a High Level Committee on the Indian Diaspora (HLCID). The Ministry of Overseas Indian Affairs was established much later in 2004, after some of the significant recommendations of the HLCID were implemented. There was also the rejuvenation of activities of both GOPIOs following official recognition of the diaspora community by the government of India and the pro-active role assumed by the Ministry of Overseas Indian Affairs.

\section{The GOPIOs and the High Level Committee on the Indian Diaspora}

Both GOPIO (NY) and GOPIO (M) claim a significant role in lobbying for the formation of the HLC on the Indian Diaspora as well as formulating various policy recommendations promoting matters of mutual interest and advancement. Both GOPIOs claimed a role in persuading the National Democratic Alliance (NDA) government to set up a High Level Committee to examine various issues and concerns of the overseas Indian community. And so a High Level Committee on the Indian Diaspora was duly appointed by the Ministry of External Affairs, Government of India, in September 2000, with the approval of the Prime Minister. Its mandate was to recommend a broad and flexible policy framework after reviewing the status, needs and roles of People of Indian Origin (PIOs) and Non-Resident Indians (NRIs).

The Committee was presided over by Dr. L. M. Singhvi, an MP and former Indian High Commissioner to the UK Members included Shri R. L. Bhatia, MP and 
former Minister of State for External Affairs, Shri J. R. Hiremath, Indian Foreign Service (Ret.), and Shri Baleshwar Agarwal, Secretary General of the Antar Rashtriya Sahyog Parishad. Shri J.C. Sharma, Secretary (NRI \& PV) of the Ministry of External Affairs, handled the secretarial duties. The Committee was expected to look at the role of PIOs and NRIs in India, the rights and facilities extended to them, and also to examine such matters as the denial of their rights and much else, including discrimination in the countries of residence.

The Committee submitted its report to the Prime Minister in January 2002, recommending various measures to resolve the problems faced by NRIs and the PIOs, drawing up, for example, country-specific plans for forging a mutually beneficial relationship, not to say facilitating their interaction and participation in India's economic development.

The HLCID has extensively examined the contemporary context of the Indian Diaspora in most of those countries where people of Indian origin have a significant presence and has tabled several recommendations for the Government to consider. Apart from its many policy recommendations, the Report of the High Level Committee on the Indian Diaspora offers a wealth of information on the Indian diaspora.

\section{HLCID Recommendations}

In its interim report, the High Level Committee on the Indian Diaspora (HLC) recommended that the government should prioritize some of the significant issues that had figured in discussions with the members of the Diaspora communities. These included:

- The observation of Pravasi Bharatiya Divas on January $9^{\text {th }}$ (the day Mahatma Gandhi returned to India from South Africa); the point of marking this annual event, which is of great significance to Indians at home and abroad, was to recognize and appreciate the role of Indian Diaspora in the promotion of India's interests.

- The institution of Pravasi Bharatiya Samman Awards to recognize eminent PIOs and NRIs.

- The establishment of Pravasi Bharatiya Bhavan, an administrative center offering a 'single-window mechanism' to facilitate diaspora interaction and engagement with India.

The HLCID has examined all the major issues - culture, education, media, economic development, health, science and technology, philanthropy, and dual citizenship with a view to recommending concrete steps for bringing the Indian Diaspora closer to their old homeland, doing so for the first time in an institutionalized manner. In order to facilitate closer interaction between India and the Diaspora and to be able to continuously monitor these evolving ties, the HLCID has suggested setting up 
an autonomous and empowered body, similar in kind to the Planning Commission, and also constituting a Standing Committee of Parliament. On some major issues like culture and the media, it is envisaged that the people and government of India will take effective steps to promote languages, philosophy, spirituality, performing arts, and ethnic Indian media among Indian Diaspora communities, with especial reference to the PIO diaspora. The HLCID has drawn a list of programs and activities through which Indian culture and media can effectively reach the younger generation in the diaspora.

The HLCID has made several recommendations in the areas of education, economic development, healthcare, and science and technology that require active participation from all three parties: the people of India, the Indian Diaspora, and the government of India. The Report of the HLCID (Ministry of External Affairs 2002) suggests that the government of India and the various state governments should try to remove all obstacles standing in the way of philanthropic and voluntary or welfare activities, especially those involving NGOs, that the members of the Indian Diaspora might wish to pursue in India.

\section{Dual Citizenship}

A significant but controversial issue - that of dual citizenship - came up for consideration by the HLCID, particularly when meeting with prominent members of the Indian community in North America and a few other advanced countries (NRI diaspora). It was argued that the granting of dual citizenship would foster investments, trade, tourism, and philanthropic contributions in India. According to the Citizenship Act of 1955, an Indian forfeits Indian citizenship when he/she acquires citizenship of a foreign country. The HLCID recommended embracing dual citizenship, but only after appropriate safeguards had been put in place pertaining to India's security concerns; that said, they saw amendments to the Citizenship Act of 1955 as inevitable. However, the HLCID did not see dual citizenship as conferring any right to participation in the electoral process, neither as a voter nor as a candidate for office, and employment in the Indian civil services was out of the question. The Government of India had already approved a scheme for granting Overseas Citizen of India status. The so-called OCI card was designed as an alternative, not as a step toward, to dual citizenship, a concession made especially to those who left India after 1947. But there is the hope that dual citizenship might prove an attainable goal in the near future. At any rate, this agenda is being actively pursued by the resolutions of GOPIO (NY).

\section{The PIO Card}

The Government of India introduced the PIO Card scheme in 1999 for all persons of Indian origin down to the fourth generation, with exceptions made for citizens of Bangladesh, Pakistan, and some other designated countries. It conferred on holders 
several economic, educational, financial and cultural benefits, placing them on a par with Non-Resident Indians. A central provision was a visa fee regime for 20 years set at US\$1000. The HLCID, after considering several representations, recommended that the fee and the period of validity should be reduced. In 2015, the PIO Card scheme has been merged with OCI Card, providing a lifetime visa. According to the HLCID Report, most of the PIOs, except for those living in North America, Europe, Australia, New Zealand, and Singapore, have not evinced interest in dual citizenship and prefer PIO Cards.

Hence, in a series of game-changing initiatives, the Government of India undertook to recognize the presence of the $20+$ million-strong Indian Diaspora, formulating new policies for building sustainable links between homeland and emigrants. Implementing the new policy initiatives, a first global meeting - the Pravasi Bharatiya Divas - between the Indian diaspora and the Indians, operating under the logo 'The Global Indian Family' , was organized for January 9-11, 2003. Subsequent conventions are being held every year in January. A new ministry was created in 2004 - the Ministry of Overseas Indian Affairs (MOIA) - a nodal body that functions as a 'one-stop shop' in all matters pertaining to overseas and non-resident Indians.

\section{Pravasi Bharatiya Divas and Pravasi Bharatiya Samman}

Pravasi Bharatiya Divas and Pravasi Bharatiya Samman are two important events for both GOPIOs, permitting them to engage in an annual stocktaking of their activities and achievements, as well as to lobby and make their resolutions and demands known to the government. It is also an occasion for the latter to showcase India's achievements, while stressing the opportunities for involving the 'diaspora as partners' in India's growth.

Pravasi Bharatiya Divas (PBDs) offer enormous opportunities for interaction between members of the Indian diaspora from different countries, but also with the Indian entrepreneurs, professionals and businesspersons who attend them. The first and the second PBDs (2003 and 2004 respectively) were held in Delhi by the Ministry of External Affairs. Soon afterwards, the newly constituted Ministry of Overseas Indian Affairs (MOIA), following the change of government in Delhi, took over the charge of organizing the PBDs from 2005 onwards in different state capitals such as Bombay, Hyderabad, Chennai, and Jaipur.

The $10^{\text {th }}$ Pravasi Bharatiya Divas was organized for January 7-9, 2012 in Jaipur, the city of palaces and gardens in Rajasthan. It was an ideal time and location for such an event, and huge crowds turned up from all over the diaspora. As on earlier occasions, the Confederation of Indian Industries managed this event, attended by

\footnotetext{
${ }^{4}$ The organizing committee of the first Pravasi Bharatiya Divas designed a logo with the slogan 'Global Indian Family - Celebrate Pravasi Bharatiya Divas' especially to reach out to the diaspora hitherto not duly recognized by the government until the Report of the High Level Committee on the Indian Diaspora recommended it in 2002.
} 
more than 2500 registered delegates from different countries, including India. The Minister for Overseas Indian Affairs hosted a banquet for the delegates to PBD followed by a cultural program. The PBD was formally inaugurated, as always, by the Prime Minister, who announced some of the policy initiatives the government proposed to take. Then followed panel discussions on issues of industrial, economic, and technological progress, the panelists being ministers and bureaucrats and members of the diaspora. The chief guest was the Prime Minister of Trinidad and Tobago, Kamla Persad-Bissessar. The second day ended with a cultural evening and dinner with cocktails. The third day commenced with the chief ministers of various states addressing the delegates, underlining the scope for participation in the developmental programs of their states and pointing to a range of incentives offered to the diaspora. The next session was interactive: delegates were able to interact directly with chief ministers, as well as with other ministers and bureaucrats, for purposes of seeking clarification on the schemes/opportunities proposed by the states. The PBD was formally declared closed by the President of India after presentation of Pravasi Bharatiya Samman to a dozen or so diaspora personalities, recognizing their contribution to community service, science and technology, or some social cause.

On the sidelines of the PBD, different states were provided with space to highlight what they are doing to promote industries and tourism. There were also stalls showcasing, for instance, the banking services, real estate, jewelry and handicrafts of Rajasthan.

\section{GOPIO (NY) and Pravasi Bharatiya Divas}

Since 2003, GOPIO (NY) has held its annual two-day convention in India, generally on January $5^{\text {th }}$ and $6^{\text {th }}$, coinciding with the Pravasi Bharatiya Divas. The PBD program offers special provision of tax-free accommodation (about 30\% discount on hotel tariffs), $50 \%$ discount on the $\mathrm{PBD}$ registration fee, and free transport from designated hotels for delegates to the venue of the PBD conference programs.

GOPIO (NY) encourages and assists its members in booking accommodation and in PBD advance registration, making sure they attend the pre-PBD convention held on the eve of PBD. They identify one of the 5-star hotels in the city hosting the PBD as the venue and book accommodation for all of the overseas delegates. On the first day, they hold the Executive Committee and General Body meetings, followed on the second day by country-specific presentations by the GOPIO executives of the respective countries. The highlight of the convention is on the first evening, which includes an address by one of the VVIPs. This could be a Chief Minister or a Cabinet Minister of the state hosting the PBD, or it might be the Minister of Overseas Indian Affairs, or even an Indian diplomat. Afterwards, the GOPIO presents its achievements during the year under review. The event culminates in a banquet honoring some distinguished Persons of Indian Origin for their community service or professional achievements. 


\section{GOPIO (M) and Pravasi Bharatiya Divas}

GOPIO (M) holds a one day convention - PIOs Dialogue with India - generally after the PBD program; the date is January $10^{\text {th }}$ and the venue is one of the hotels where their members are staying. The GOPIO (M) executive coordinates and organizes this event. Three panel discussions are convened after an inaugural session addressed by the Minister of Overseas Indian Affairs, Ministers from PIO countries such as Mauritius, South Africa, Sri Lanka, Malaysia, and Singapore. The post-PBD Convention ends with a decision being taken about GOPIO (M)'s next event - a mini-PBD, say, or the International GOPIO Convention. The Malaysian delegation generally outnumbers all other delegations to the PBD, followed by Sri Lanka and the United States.

\section{Bringing the GOPIOs together}

Attempts have been made to bring the two GOPIOs together by the Chairman of the HLC on the Indian Diaspora, Dr. L.M. Singhvi, as well as several well-wishers from the diaspora. The international convention of Pravasi Bharatiya Divas is a significant achievement on the part of the Indian Government, mobilizing both PIO and NRI diaspora segments around a common platform, but the effort to unify them still has some way to go. The Executive Committees of both GOPIOs were persuaded to attend each other's Conventions during the PBD in January 2010 but as of 2016 no solution is in sight for their merger.

The differences between the two streams of the Indian diaspora - PIO and NRI can be traced to their very formation. As mentioned earlier, the PIO diaspora, constituted by the $3^{\text {rd }}, 4^{\text {th }}$ or $5^{\text {th }}$ generation of descendants of 'indentured laborers,' was recruited predominantly from the poorer, deprived and untouchable sections of Indian society, who were even forced to board the ships chartered to take them to the various European plantations. Their further subjugation as 'slaves' under the ruthless British and other European planters only added to their misery, distancing them from their own people left behind in India. The majority of these emigrants under the indentured labor system, as we saw, lost contact with their families back home in India, and they also became alienated from their mother tongue in the course of settling down in the plantation colonies.

The PIO diaspora consider themselves denied of their due position as the Indian diaspora, since the new policy initiatives by the government primarily address the needs of the 'Dollar Diaspora,' i.e. the NRI diaspora. They believe that NRIs and NRI diaspora members, particularly those from North America and Europe, are well connected with India and already have a firm foothold there. They were neither persecuted nor deterritorialized, but had immigrated to greener pastures for lucrative jobs and business careers. They are affluent and have bank balances to invest in India or carry out business with India, as a result of which they demand dual citizenship. 
The PIO diaspora, on the other hand, see themselves as the 'unfortunate children of Mother India,' deserving attention and support as the true Indian diaspora, rather than the much later NRI diaspora from the developed countries.

The NRI diaspora, as mentioned earlier, comprises the first or second generation of Indian immigrants from the middle and upper classes and castes of urban India, who had opportunities for an elite education and job placement. They have the best of both worlds, the world of India and the world of the developed countries. Besides frequent family visits, they evince a keen interest in economic and political spheres in their places of origin. They have gained leverage with the Ministry of Overseas Indian Affairs, not only in seeking favorable policy initiatives but also in having their candidature considered for the award of Pravasi Bharatiya Samman.

The diversity and the distance between the NRI and the PIO diaspora are eminently visible where they have an opportunity to converge. For instance, the Indians who have directly immigrated to New York largely head for Jackson Heights, where they have created a 'Little India,' while the 'East Indians,' as they are popularly called in the Caribbean countries of Trinidad and Tobago, Guyana and Surinam, generally head for Richmond Hills, where the 'twice migrant' Indian community has created its 'Little India' along with dhal-roti and goat, 'doubles,' chatney music and dance. Except for the Indian national celebrations of Independence Day and Republic Day, organized by the Indian Consular Office, they hardly come together for any family or socio-cultural events. Jackson Heights and Richmond Hills seldom meet, clearly drawing boundaries between the two. The barriers are unlikely to disappear in the near future.

\section{Global Organizations of the Regional/Linguistic Diaspora}

The articulation of regional, linguistic or caste identities and belonging has given rise to a regrouping of diaspora communities at the global level. These regional/linguistic groups have established their own global organizations to promote their cultural, socio-economic, political, regional and linguistic interests across nation states, including their region of origin. For instance, there are Telugu, Gujarati, Punjabi global organizations that have their patronage in states like Andhra Pradesh, Gujarat and Punjab (briefly discussed below). It is interesting to note the absence of a NRI and PIO diaspora distinction among these regional/linguistic global organizations. In fact, initiatives for diaspora involvement in developmental activities are taken at the local or regional levels to which the diaspora originally 'belonged.' While the diaspora policies are initiated at the national level, it is the state/provincial govern-

\footnotetext{
5 Chatney is a word used in Indian languages for the spicy accompaniment served with snacks and this word is used to refer to the music and dance form - chatney music and dance - created from the fusion of Bhojpuri folk songs and dances accompanied by dholak (drum), harmonium and Western guitar by Indo-Caribbean singers and dancers.
} 
ment that pursues 'their' diaspora pro-actively, partnering with them for advancement in all spheres of life. The regional diaspora has emerged as a significant player in the growth story of its place of origin. Some of the members of pan-Indian global organizations like GOPIO (NY) or GOPIO (M) may also be members of regional diaspora organizations, provided that they, their parents or ancestors originally 'belonged' to that region and vice versa.

\section{The World Telugu Federation (WTF)}

The World Telugu Federation (WTF) is an NGO set up in 1992 to promote Telugu language and culture among overseas Telugus. The initiative came from Chennapuri Andhra Maha Sabha, the Telugu Association of North America (TANA), and the Tamil Nadu Telugu Federation (TNTF). The First Convention of the WTF was inaugurated by Sri N.T. Rama Rao, the then Chief Minister of Andhra Pradesh, and was duly held in New York in 1992. Today WTF has emerged as a coordinating body for most of the Telugu associations worldwide, including the International Telugu Institute. In addition, it liaises with Andhra Pradesh government and other organizations.

The leadership came from leading Telugu film producers such as Dr. V.L. Dutt and V.S. Rao. The first WTF conference was held in Madras (December 1994) with a second following in Hyderabad (December 1996). The third Conference was organized in New Delhi (December 1998), followed by a fourth at Visakhapatnam (December 2000). The only conference held outside India so far was in Singapore (December 2002). Besides promotion of Telugu language and culture, the WTF has broadened its canvas to include business, tourism, education, and collaboration in science and technology. The Federation has also emerged as a forum to attract trade, commerce and investments in Andhra Pradesh by the Telugu diaspora. Members of both the PIO and New Telugu diasporas attend these conferences in large numbers and renew their links with the motherland. Regional and linguistic sentiments of 'belonging together' are often stronger than pan-national identity.

\section{Vishwa Gujarati Samaj (VGS)}

Founded in 1989, Vishwa Gujarati Samaj (VGS) is an International Organization of the global Gujarati community. It has grown from strength to strength over a span of 22 years and can boast membership from 101 countries. VGS is registered as a Public Trust under the registration no. F-1927, Ahmedabad under the Bombay Public Trust Act, and is a registered society under section $80(\mathrm{G})$ of the Indian Income Tax Act. VGS is governed by its members and office bearers settled throughout the world. The apex body of Vishwa Gujarati Samaj is registered as 'Vishwa Gujarati Samaj (USA)-INC.' under section 402 of the Not-For-Profit Corporation Law of the state of New York. It has its head office in Ahmedabad, India and enjoys exemption from Federal Income Tax under section 501 (A) of the Internal Revenue Code (USA). 
Membership is open to all Gujaratis, and to all those who understand the Gujarati language or belong to Gujarati associations throughout the world and accept the aims and objectives of the organization. VGS also undertakes projects and programs in accordance with broad objectives, such as organizing social, cultural, educational, environmental, and humanitarian activities for Gujaratis settled around the world.

The Government of Gujarat set up the Non-Resident Gujarati Foundation (NRGF) in 1998, besides launching many schemes targeting NRGs, not only to attract investment in Gujarat but also to enhance communication. The World Gujarati Meeting held at Vadodara on January $4^{\text {th }}, 1999$ attracted NRGs from many parts of the world, such as Uganda, New Zealand, the United States, the United Kingdom, UAE, Australia, and South Africa. Gujaratis are well known for their close networking along family, caste and religious lines, both in India and abroad.

International Gujarati associations and organizations play a very significant role in promoting transnational networks; they seek to unite all Gujaratis for the benefit of Gujarat and to preserve Gujarati culture, its traditions, and folklore. There are considerable numbers of Gujaratis living in the United States, the United Kingdom, Canada, and East Africa. Overseas Gujaratis have formed these associations to pursue and safeguard their interests at the local and global levels. Their solidarity with fellow Gujaratis could be gauged by the global response to the crises in Uganda, the Middle East, and Fiji. The unprecedented earthquake of January 26, 2001 brought together Gujartis worldwide, mobilizing men and materials to enable immediate and long-term recovery from the massive damage. In order to rebuild economy and infrastructure, they raised funds on a grand scale - not just at a personal but also an organizational level.

\section{The Global Punjabi Community}

Punjabis have maintained strong networks - sociocultural, economic, religious and political - with their kith and kin around the world, as well as with their relatives back home in Punjab. These networks are manifested in remittances sent to the families left behind, by involvement in various national and international associations, and by visiting the homeland for manifold reasons. Further, the process of maintaining these networks is facilitated by the spectacular progress in global media and communication technology.

With the help of the Internet, the world wide web and news groups, plus interactive communication via email, diasporic Punjabis form today the 'Global Punjabi community.' As a pro-active state, the Government of Punjab has operated Pravasi Punjabi Divas since 2003, inviting Non-Resident Punjabis (NRPs) to interact with the leading industrialists and businessmen of Punjab. Following the Government of India, distinguished members of the overseas Punjabi community were honored with the status of 'Punjabi Gaurav Sanman.' The state of Punjab offers incentives to NRPs for setting up industrial enterprises on a preferential basis, providing 'Single Window Clearance' for investment proposals. The state established a Ministry of NRP Affairs 
in 2002, with its Secretariat at Chandigarh; it created an NRP Helpline to obtain feedback from NRPs, especially those from Canada, the United Kingdom and the United States. The Government of Punjab started a new scheme called the Mera Pind Initiative in 2002, offering matching grants (50\%) to NRPs for funds invested in 'development projects' such as rural infrastructure or investment in ancestral villages (Kaur 2011).

\section{In Conclusion: Observations and Reflections}

Diaspora global organizations play a significant role in articulating issues, challenges and opportunities facing the diaspora community and the motherland/ancestral land, keeping in mind the protection and promotion of wellbeing and common interests of both parties. Contemporary globalization has facilitated more than ever before the bringing together of dispersed people and communities, taking those who 'belong' to a common place of origin and connecting, or rather reconnecting, them on a truly global basis. The global organizations of the Indian diaspora, based as they are on pan-Indian, regional/linguistic, religious, or caste identities, have emerged during the last decade of the $20^{\text {th }}$ century following the advent of technologies of superfast travel and also information and communication highways.

Today the Indian diaspora communities, no less diversified than India itself, are actively engaged in reconnecting with the people and places of their origin, extending what it means to 'belong' to those communities or regions that they, or their ancestors, left when they immigrated to global destinations. Perceptions of Indian identity among the Indian diaspora vary based on how members are situated in the host country. In Mauritius, for instance, where PIOs form a majority, Indian identity is perceived through its constituents of Hindus, Tamils, Telugus and Marathis (Bhat and Bhaskar 2011), while in Trinidad they are primarily categorized as PIOs, with little deviation. However, the NRI diasporas in the United Kingdom and United States exhibit all the diversities for which India itself is known. Thus, depending on context, the Indian diaspora responds to the situation on the ground by forming 'Little India,' 'Little Punjab,' or 'Little Gujarat'; thus, communities assume one or other of multiple identities and come to define themselves as belonging to a nation, region/language, religion, or caste. Another significant distinction that vertically differentiates the Indian diaspora is that between its PIOs and NRI sections. The former are largely 'children of the indentured,' whose parents or grandparents immigrated to colonial British and other European plantations, whereas the latter immigrated to the developed West after India gained independence.

Despite the diversities, Indians have a strong sense of unity that is often described in terms of 'unity in diversity': 
Though the concept of India is barely 53 years old, 'Indianness' has evolved over the centuries. Certainly the freedom movement against the British saw its consolidation further. Indianness has a geographical connotation but is not any longer spatially limited. It includes the notion of a nation marked by its cultural confluence not bound by frontiers, for it is transnational in character. (Bhat 2006)

India today stretches far beyond her borders, and the Indian diaspora, thanks to the new policy initiatives of the Government of India, is set to take India beyond India. It shares equally in the achievements of the Indian Space Research Organization and in the dynamism of Silicon Valley in California. Needless to say, any disaster or tragedy striking any Indian anywhere in the world is a matter of concern to all Indians wherever they may be. The news of 27 September (Hindustan Times 2016) from Washington that the Indian American community in the United States has petitioned the White House to designate Pakistan a state sponsor of terrorism, this coming only days after a bill to this effect was tabled in the US Congress by two powerful lawmakers (following an incident where Pakistani terrorists killed 18 Indian soldiers at Uri in Jammu and Kashmir), amply illustrates the reality of India emerging beyond India.

\section{Acknowledgments}

This chapter is based on field studies carried out in Mauritius, Malaysia, South Africa, Sri Lanka, the United States, and the United Kingdom. It also reflects input from global conventions held by Indian diaspora organizations, on the occasion of Pravasi Bharatiya Divas celebrations in different parts of India. I sincerely thank my interlocutors in 'India beyond India' conference and the editors of this volume for their valuable suggestions on an earlier draft of this chapter. 


\section{References}

Bhat, Chandrashekhar. 1993. "Indian Ethnic Associations in London: Search for Unity in Diversity." In Sociology of Development and Change, edited by Chandrashekhar Bhat, Laxmi N. Kadekar, and Ranga K. Rao. New Delhi: Orient Longman.

. 2006. "Continuity and Change in the Perception of 'Indianness': Issues of Identity among Indians at Home and in the Diaspora." In Peripheral Centres, Central Peripheries: India and its Diaspora(s), edited by Martina Ghosh-Schellhorn and Vera Alexander, 243-50. Berlin: LIT.

Bhat, Chandrashekhar, and T. L. S. Bhaskar. 2011. "Locality and Identity in the Indian Diaspora: Reinvention of Regional/Linguistic Diversities in Mauritius." In Diversities in the Indian Diaspora: Nature, Implications, Responses, edited by N. Jayaram, 114-24. New Delhi: Oxford University Press.

Brah, Avtar. 1996. Cartographies of Diaspora: Contesting Identities. London: Routledge.

Clarke, Colin G., Ceri Peach, and Steven Vertovec, eds. 1990. South Asians Overseas: Migration and Ethnicity. Cambridge: Cambridge University Press.

Clifford, James. 1994. "Diasporas." In "Further Inflections: Toward Ethnographies of the Future." Special issue, Cultural Anthropology 9 (3): 302-38.

Cohen, Robin. 1997. Global Diasporas: An Introduction. London: UCL Press.

Featherstone, Mike, Scott M. Lash, and Roland Robertson, eds. 1995. Global Modernities. London: Sage.

Hindustan Times. 2016. "White House Petition on Pakistan Terrorism Crosses 100,000 Signatories." September 27. http://www.hindustantimes.com/wor ld-news/white-house-petition-on-pakistan-terrorism-crosses-100-000-signa tories/story-YtkExJio0xFRZ3ZmVEAAGO.html.

Jain, Sulekh C. 2009. "Jain Diaspora Vision and Opportunities.” Accessed October 02, 2017. http://www.jaina.org/resource/resmgr/jain_diaspora/scjain-diaspo ra__vision__op.pdf.

Jayaram, N., ed. 2011. Diversities in the Indian Diaspora: Nature, Implications, Responses. New Delhi: Oxford University Press.

Kaur, Mandeep. 2011. "Canadian-Punjabi Philanthropy and its Impact on Punjab: A Sociological Study.” PhD dissertation, Punjabi University, Paiala. http://hdl. handle.net/10603/8022.

Lechner, Frank. 2005. "Globalization.” In Encyclopedia of Social Theory. Vol. 1, edited by George Ritzer, 330-33. Thousand Oaks: Sage.

Levitt, Peggy, and Nina Glick Schiller. 2004. "Conceptualizing Simultaneity: A Transnational Social Field Perspective on Society." International Migration Review 38 (3): 1002-39. doi:10.1111/j.1747-7379.2004.tb00227.x.

Ministry of External Affairs. 2002. "Report of the High Level Committee on Indian Diaspora.” New Delhi: Government of India. Accessed October 02, 2017. http://indiandiaspora.nic.in/contents.htm. 
Nonini, Donald M. 2005. "Diasporas and Globalization." In Encyclopedia of Diasporas: Immigrant and Refugee Cultures Around the World, edited by Melvin Ember, Carol R. Ember, and Ian Skoggard, 559-70. New York: Springer Science+Business Media.

Robertson, Roland. 1992. Globalization: Social Theory and Global Culture. London: Sage.

__ 1995. "Glocalization: Time-Space and Homogeneity-Heterogeneity." In Global Modernities, edited by Mike Featherstone, Scott M. Lash, and Roland Robertson, 25-44. London: Sage.

Tatla, Darshan S. 1999. The Sikh Diaspora: The Search for Statehood. London: UCL Press.

Tinker, Hugh. 1974. A New System of Slavery: The Export of Indian Labour Overseas 1830-1920. London: Published for the Institute of Race Relations by Oxford University Press.

Vertovec, Steven. 2000. The Hindu Diaspora: Comparative Patterns. London: Routledge. 